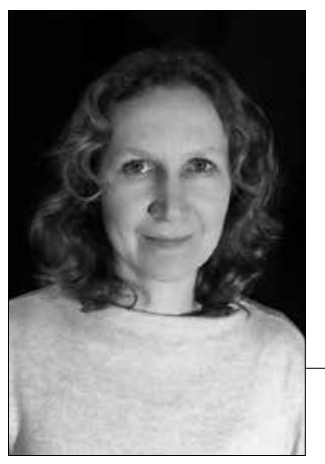

https://doi.org/10.24101/logos.2018.21

\title{
AUDRONĖ DARAŠKEVIČIENE்
}

Lietuvos istorijos institutas

Lithuanian Institute of History

\section{ETNINIO TAPATUMO RIBOŽENKLIAI: RÜPINIMOSI VAIKU PRAKTIKA LIETUVOJE, ISPANIJOJE IR PRANCŪZIJOJE}

\author{
The Border Marks of Ethnic Identity: \\ Parenting Practices in Lithuania, Spain and France
}

\begin{abstract}
SUMMARY
The article reflects on the differences of parenting in Lithuania and Southern Europe (Spain and France), arising in the emic perspective of migration. Through an analysis of interpretations on everyday life practices of parenting related to the discourse of ethnic identity, it concentrates on the problem of ethnic identity. The article is based on the theory of ethnologist, Orvar Löfgren. The theory claims that in relation to the "Other", the small details of everyday life become symbolic representations or distillations of central national ideas or patterns of behavior. The article concludes that the symbolic representations of a particular nation or culture are produced in dependence upon characteristics of the "Other" nation or culture, with which the first one is being compared.
\end{abstract}

\section{SANTRAUKA}

Straipsnyje migracijos kontekste analizuojama emic perspektyvoje atsirandanti kasdienio tèvų rūpinimosi vaikais Lietuvoje ir Pietų Europoje (Ispanijoje bei Prancūzijoje) skirčių refleksija. Gilinamasi į etninio tapatumo problemą, analizuojant kasdienio tėvų rūpinimosi vaikais interpretacijas, susijusias su etninio tapatumo diskursu. Remiamasi etnologo Orvaro Löfgreno teorija, teigiančia, kad susidūrimo su kitu situacijoje, kasdienybės detalès tampa simbolinėmis reprezentacijomis, padedančiomis išgryninti vienos ar kitos šalies bruožus, pagrindines tautos idejjas arba elgesio modelius. Prieinama prie išvados, kad tam tikrą tautą ar kultūrą nusakančios simbolinės reprezentacijos konstruojamos atsižvelgiant i tai, kokiomis savybèmis pasižymi arba nepasižymi kito pozicijoje esanti tauta ar kultūra. 


\section{IVADAS}

Problema, kuriai pastarųjų dešimtmečių Lietuvos etnologijoje bei antropologijoje skiriama itin daug dèmesio, yra globalizacijos procesu paliesto pasaulio aktualijas atspindintis tapatumo klausimas ${ }^{1}$. Teoriniai tapatumo apibrèžimai įvairūs, sąvoka vartojama plačiai ir skirtingai ${ }^{2}$. Šiame straipsnyje pasirinktas etnologo Orvaro Löfgreno apibūdinimas: tapatumas suvokiamas kaip savęs ar savo grupès apibrèžimas, kuriame svarbų vaidmeni atlieka sąveika su kitomis grupemis arba interesais ir jų bei savęs priešinimas ${ }^{3}$.

Löfgrenas atkreipia demesi, kad nagrinejjant tapatumo problema, verta atsigręžti i kasdienes praktikas ir patirtis, nes būtent mąstant apie jas išgryninami vienos ar kitos tautos bruožai. Remiantis juo, pabandžius sudaryti nacionalinių simbolių dešimtuką, greičiausiai i ji patektų smulkios kasdienybès detalès, atspindinčios tautos pagrindines idejas arba elgesio modelius ${ }^{4}$. Minètas autorius tautos arba nacijos nusakymui atrinktas kasdienybės detales - kasdienybëje tūnančius rutinos elementus - vadina simbolinèmis reprezentacijomis. Būtent šios detalès padeda braižyti riboženklius tarp to, kas suvokiama kaip sava, ir to, kas laikoma kita.

Nemaža dalis antropologu pažymi, kad migracijos kontekste ${ }^{5}$ i etninio tapatumo diskursą patenka kasdienio rūpinimosi vaikais refleksija. Pavyzdžiui, Ariane Utomo atkreipia demesí, kad būtent kasdienybejje besireiškiančios idèjos apie kūdikio maitinima, migdyma, jo dienotvarkès organizavima, bendruomenès vaidmeni auginant vaiką skatina Australijoje gyvenančias indonezietes daryti skirtumą tarp namu, savos, t. y.
Indonezijos, ir kitos, t. y. Australijos, kultūros $^{6}$. Livia Jimenez Sedano atskleidžia, kad i Ispaniją imigravę dominikiečiai pagal tam tikrus tèvų rūpinimosi vaiku bruožus išskiria dominikietišką ir ispanišką rūpinimosi vaiku stilių ${ }^{7}$. Hemalatha Ganapathy-Coleman pažymi, kad JAV gyvenantiems indams tam tikrais bruožais pasižymintis kasdienis elgesys su vaiku yra vienas indų elgesio kultūrą apibrèžiančių ženklų ${ }^{8}$.

Remiantis Lofgrenu, migracijos situacijoje atsirandančios sąsajos tarp kasdienio rūpinimosi vaiku ir tapatumo diskurso nèra atsitiktinis dalykas - būtent dèl susidūrimo su kitu tapatumas itin greitai igauna aiškius kontūrus kasdienybèje ${ }^{9}$. Kasdienybės aspektai kaip etninę tapatybę padedantys konstruoti ženklai aptariami daugelio Lietuvos etnologų darbuose ${ }^{10}$. Tačiau rūpinimosi vaiku kultūra ${ }^{11}$ kaip etninio tapatumo diskurso dalis Lietuvos tyrëjų dèmesio nèra susilaukusi.

Straipsnyje siekiu išsiaiškinti, kaip riboženklius tarp sava ir kita braižo migracijos kontekste lietuviai, ispanai ir prancūzai analizuodami rūpinimosi vaiku kultūrą. Dėmesi sutelksiu ị klausimus: 1) kaip rūpinimosi vaiku praktika tampa etninio tapatumo riboženkliais susidūrimo su kitu situacijoje; 2) kaip lietuvišką elgesį nusakančios simbolinès reprezentacijos konstruojamos, žvelgiant iš dviejų skirtingu - ispaniškos ir prancūziškos - perspektyvų.

Vienas esminių šio tyrimo metodų yra stebejimas dalyvaujant ${ }^{12}$. Kitas svarbus metodas - struktūruoti ir pusiau struktūruoti interviu. Juos atlikau su 20 pateikèjų. 
Pirmoji pateikejjų grupé - tai 9 žmonės, sudarę mišrias lietuvių ir ispanų santuokas arba kitais būdais kuriantys ryšius su Lietuva ir Ispanija. Tai 5 Lietuvoje gyvenantys arba kelerius metus gyvenę ispanai (1 vyras, 4 moterys) iš mišrių šeimų su lietuviais ir 4 lietuviai (1 vyras, 3 moterys): 2 iš jų sudarę mišrias santuokas su ispanais ir 2 lietuvès, gyvenančios Ispanijoje.

Antroji pateikejju grupè - tai 11 žmonių, sudarę mišrias lietuvių ir prancūzų santuokas arba kitais būdais kuriantys ryšius su Lietuva ir Prancūzija. Tai 4 (1 vyras, 3 moterys) Lietuvoje gyvenantys prancūzai iš mišrių šeimų su lietuviais ir 7 lietuvės: 4 gyvena Prancūzijoje mišriose šeimose su prancūzais, 2 gyvena mišriose šeimose su prancūzais Lietuvoje, 1 kelerius metus Prancūzijoje dirbo aukle.

Reikètu patikslinti, kad tyrimo metu terminu lietuviai kai kurie pateikèjai vadino visus Lietuvos gyventojus nepriklausomai nuo ju tautybès ${ }^{13}$. Lygiai taip pat kalbant apie prancūzus arba ispanus kai kuriais atvejais buvo kalbama ne apie tautinę, o apie kultūrinę tapatybę. V. Savoniakaite pažymi, kad nors terminas etninis lietuvių kalbos žodyne apibrèžiamas kaip reiškiantis priklausymą kuriai nors tautai, bendriausia prasme etniškumas rodo, kokiai žmonės priklauso visuomenei, kaip jie susiję kultūriškai ${ }^{14}$. Remiantis šiomis pastabomis, straipsnyje sąvokos lietuvis, prancūzas arba ispanas vartojamos kaip nuoroda ị tapatinimąsi su kilmès šalimi.

\section{LIETUVA VERSUS ISPANIJA IR PRANCŪZIJA}

Tyrimo metu išryškejjo keletas rūpinimosi vaiku bruožų, kurie lietuvišką elgesio su vaiku kultūrą skiria ir nuo ispaniškos, ir nuo prancūziškos. Ši takoskyra ryškejja aptariant (1) vaiko išleidimo ì darželi amžių; (2) vaiko gebejjimo būti be suaugusiụjų priežiūros sampratą; (3) tèvų elgesi vaiko ligos atveju; (4) vaiko socializaciją prie stalo ir (5) tèvo vaidmeni šeimoje.

Vienas ryškiausių riboženklių, pateikejjų pasakojimuose nubrèžtų tarp lietuviškos elgesio su vaiku kultūros ir būdingos abiem analizuojamoms Pietų Europos šalims, yra nuostatos dèl vaiko išleidimo i darželį. Visi pateikèjai kaip vieną svarbiausių rūpinimosi vaiku kultūros bruožų Lietuvoje pamini ilgas vaiko priežiūros atostogas, kurios sudaro prielaidas vaikui būti su mama ar tèčiu iki 2 metų. Būtent dèl to teigiama, kad
Lietuvoje kūdikystè ir ankstyvoji vaikyste tęsiasi ilgiau (prancūzas, gyvenantis Lietuvoje). Ispanijoje ir Prancūzijoje, pasak pateikèjų, kūdikystė yra trumpesne, nes Ispanijoje vaiko susilaukusios mamos turi teisę $\mathfrak{i}$ apmokamas atostogas 16 savaičiú, Prancūzijoje - 3 mènesius (turint daugiau vaikų - 6 mènesius). Pateikejjai pažymi, kad ilgesnés vaikystès Lietuvoje prielaida yra ne tik čia vykdoma šeimos politika. Dauguma respondentų teigia, kad Lietuvos visuomeneje vyrauja nuostata, jog vaikui pirmuosius, antruosius, o idealiu atveju ir trečiuosius metus geriau augti namie, šeimos aplinkoje. Ši nuostata Lietuvoje, pasak čia gyvenančių kitataučių, tokia stipri, jog kitokių nuostatų šiuo klausimu besilaikančios mamos jaučia spaudimą. Lietuvoje gyvenančios prancūzès teigimu: aš $i$ darba išéjau nuo 8 menesiu, tai man visi sako: kaip tu gali 
atiduoti vaika svetimiems žmonèms? Lietuvoje gyvenanti ispane taip pat nurodo: kai aš vaika išvedžiau i darželi nuo metu, čia dažnai išgirsdavau: "vargšelis vaikas". $\mathrm{O}$ Ispanijoje ir Prancūzijoje, pasak šiu pateikejju, vyrauja nuostata, jog metu vaikui reikia bendrauti su bendraamžiais.

Tačiau aptariant vaiko gebëjimo būti be suaugusiųju priežiūros sampratą išaiškëja, kad vaikysté yra ilgesne aptariamose Pietų Europos šalyse. Pasak pateikeju, Lietuvoje vaikui jau nuo 5-6 metu suteikiama laisvè būti savarankiškam be suaugusiuju priežiūros, o tiek Ispanijoje, tiek Prancūzijoje vaikas be suaugusiujų priežiūros nepaliekamas iki pat 11-12 metų:

O! Lietuva - tai vaikų laisvès kraštas (ispanè, ištekèjusi už lietuvio).

Lietuvoje yra normalu, kad penkerių metu vaikas išeina vienas i kiema, žaidžia. Prancūzijoje tai yra neissivaizduojamas dalykas. Iš viso neįsivaizduojamas dalykas. Mes gyvename name, ir aplinkui gyvena šeimos su vaikais, bet iš viso nèra mados, kad vaikai išeitu i kiemą kartu pažaisti. Jei išeina, tai išeina tik kartu su mama. Jei vaikai vieni žaidžia ar vaikšto po gatves, čia reiškia, kad tèvai nelabai rūpinasi. Dažniausiai tai vaikai iš daugiaaukščiu, kur gyvena... kaip sakyt... juodo gymio žmonès. Mūsų dešimtmetị mes kartais paliekame namuose, bet irgi sakome - niekam neatidaryk, niekam nesakyk, nes... tai yra nelegalu. Jau galima - kai jie išeina į koledža, nuo 11-12 metų. Tada jie jau yra laisvi ir tèvai ju jau nebevežioja. Jie prižiūrimi, bet jau ne taip. O iki tol - išeiti iš mokyklos reikia leidimo, yra nuolatinè kontrolè (lietuvè, gyvenanti Prancūzijoje).

Kita itin svarbi takoskyra tarp lietuviškos ir analizuojamoms Pietų Europos šalims būdingos elgesio su vaiku kultū- ros, išryškinama beveik visu pateikèju, yra tėvų bei kitų visuomenès narių elgesys vaiko ligos atveju. Pasak Lietuvoje gyvenančios prancūzès:

Oi! Tai juokingiausia tema. Aš manau, kad čia yra skirtingi žodynai. Lietuvoje sloga - būsi namie visą mènesi, tu sergi. Bet juk tai tik sloga! Paracetamolis, ir viskas. Jei paracetamolis neveikia, gali likti namie vieną dieną bet ne visą savaitę! $\mathrm{Na}$, jei vaikas serga bronchitu, jis kosti tris savaites, bet ar reikia likti namie 3 savaites? Ne! Mes tokiu atveju neiname i darželį savaitę, o paskui jis dar kosti porą savaičiu bet tai jau nieko blogo, i darželi eiti tikrai galima. Vaikas turi socializuotis! <.. > Mano vyras [lietuvis. $-A$. D.] sako, kad šis požiūris susijęs su oru. Bet tai netiesa, nes Prancūzija didelè, i̇vairiausi klimatai, Pirènuose būna -20, bet požiūris yra tas pats. Tai absoliučiai kultūrinis dalykas. Nežinau, kodèl ligos čia yra apsėdimas. Jei palieti darželio temą - iškart: oi! sirgs sirgs sirgs.

O Prancūzijoje gyvenanti lietuvė mano, kad Prancūzijoje i̇ vaiko ligą žiūrima neatsakingai:

Lietuvoje, kai vaikui temperatūra, sloga su vaiku yra būnama namuose, vaikas yra gydomas namuose, jis gali sèdèti savaitę, kol absoliučiai išgis. Čia [Prancūzijoje. $A$. D.] būtų nę̇sivaizduojama, kaip galima sèdèt namuose su vaiku, kuris yra šiek tiek sergantis. $<\ldots>$ [Prancūzijoje. $-A$. D.] vaikus leidžia sergančius į mokyklą, duoda vaistu ir tikisi, kad iki 5 vakaro vaikui nepakils iki 38 ir tẻvų neiškvies i mokyklą.

Skirtingos tèvų elgesio normos vaiko ligos atveju, pasak pateikèju, yra įsitvirtinusios ne tik tèvu nuostatose, bet ir institucineje socialinès apsaugos sistemoje. Lietuvoje gyvenančios ispanès teigi$\mathrm{mu}$, Lietuvoje sloguojančio ar kosinčio 
vaiko nepriima i darželí, o gydytojai paskiria namų režimą. Prancūzijoje gyvenanti lietuvė ten egzistuojančią socialinès apsaugos sistemą komentuoja taip: [Prancūzijoje. - A. D.] i mokykla gali eiti, kol nebūna 38 laipsniai temperatūros. Tévai per metus turi 5 apmokamas dienas, kurias gali būti su sergančiu vaiku. Visos kitos dienos yra tavo atostoginiu saskaita. <...> Mes esame suspausti tos sistemos ir nori nenori tu negali būti su sergančiu vaiku namuose.

Dar viena ryški takoskyra tarp lietuviškos ir abiem Pietų Europos šalims būdingos elgesio su vaiku kultūros ryškejja aptariant tokì kasdienybės elementą kaip vaiko socializacija prie stalo. Vienbalsiai pažymèta, kad Lietuvoje daug mažiau dèmesio skiriama vaiko mokymui laikytis bendro šeimos valgymo tvarkos, o Pietų Europos šalyse vaikai nuo mažumės mokomi valgyti kartu su šeima: palaukti, kol visi susirinks, sèdèti prie stalo, kol visi pavalgys, suvalgyti visą patiekiamą maistą:

Ispanijoje yra svarbu, kad valgydami visi pabūtų kartu, pabendrautų. Dèl to valgo visi kartu griežtai nustatytomis valandomis: 10 val. pusryčiai, 14 val. pietūs. Lietuvoje daug laisviau: pietauji kartais 12, o kartais 15 val. Kai kas grižta iš kur nors, tai ir pavalgo vienas. Ten [Ispanijoje. - A. D.] daugiau edukacijos dèl maisto ir mokykloje: mokoma palaukti, kol pavalgys visi. Be to, mokoma visko paragauti, valgyti viską (ispanè, gyvenanti Lietuvoje).

Už prancūzo ištekejjusi lietuvè pasakoja:

Iš pradžių mane erzindavo tai, kad vyras neleidžia vaikams pakilti nuo stalo tada, kai jie pavalgè. Bet po to aš pamaniau, jog tai yra visai smagu, kad vaikai pavalgè, bet vis tiek kartu sedi, o ne ten bèga lakstyti. Pastebejjau, kad stebint kitų lietuvių šeimas, mane jau erzindavo patys lietuviai - yra stalas paruoštas, atrodo, visi ateis, susès ir valgys - ne, lietuvių vaikai ateina, capt capt capt kažką griebia ir pabèga. <...> Man tai jau - oi, kaip nemandagu. Nors seniau to nepastebedavau.

Takoskyra tarp Lietuvos ir Pietų Europos driekiasi ir aptariant tèvo vaidmenị šeimoje. Daugelio pateikëju nuomone, nors tèvo vaidmuo prižiūrint vaiką pastaruoju metu Lietuvoje labai padidejo, vis tiek Lietuvos tèvai prižiūrint ir auginant vaiką dalyvauja daug mažiau, nei aptariamose Pietų Europos šalyse: $A \check{s}$ buvau labai nustebusi, kad mano vyras [lietuvis. - A. D.] pirmais metais vaikui gimus taip mažai buvo namie. Mes labai daug diskutavome dèl to, kad jis mažai su vaiku bendrauja. Aš buvau ipratusi, kad abu tèvai dažnai būna namie, visi bendraujame (ispanè, gyvenanti Lietuvoje).

Taigi galima konstatuoti, kad kalbèdami apie îvairias savo gyvenimo kasdienybės situacijas, pateikejjai dažnu atveju mintis dèsto tokiu principu: „aš taip elgiuosi, nes esu prancūzè", "aš taip nedarau, nes esu lietuvè " arba "aš - ispanas - taip darau, nes taip daro ispanai“. Migracijos kontekste rūpinimosi vaiku praktika tampa priemone, padedančia išgryninti vienos ar kitos šalies bruožus, pagrindines idejjas arba elgesio modelius. Tyrimas leidžia pritarti tyrèjams, teigiantiems, kad susidūrimo su kitu situacijoje kasdienybès detalès, šiuo atveju - rūpinimosi vaiku praktika - gali tapti simbolinemis reprezentacijomis, padedančiomis braižyti etninio tapatumo žemèlapius. 


\section{LIETUVA VERSUS ISPANIJA IR LIETUVA VERSUS PRANCŪZIJA}

Kita svarbi ižvalga, kurią paskatino tyrimas, yra tokia: migracijos situacijoje tam tikrą kultūrą nusakančios simbolinès reprezentacijos suformuluojamos atsižvelgiant ne tik i pastebėtus aptariamos kultūros požymius, bet ir ị tai, su kokia kita kultūra ji gretinama. Norèdama pagrịsti ši teigini, aptarsiu lietuvišką elgesį nusakančias simbolines reprezentacijas, išryškinamas žvelgiant iš dvieju skirtingu perspektyvų: 1) pateikèjų, kuriančiu ryšius su Lietuva ir Ispanija; 2) pateikejjų, gyvenančiu lietuvių ir prancūzų kultūrų sankirtoje.

\section{Lietuva versus Ispanija}

Lietuvių ir ispanu pateikëju grupèje išryškëjo, kad elgesys su vaiku Lietuvoje ir Ispanijoje itin smariai skiriasi šiais aspektais: vaikui skiriamo demesio, vaiko disciplinavimo, globos ir savarankiškumo ugdymo. Būtent šie kasdienio elgesio aspektai tampa riboženkliais, padedančiais migracijos kontekste susitikusiems lietuviams ir ispanams nubrèžti ribas tarp savos ir kitos kultūrų ir konstruoti savo asmeninę tapatybę.

Visuomenès nariu vaikui rodomas dèmesys pateikèju pasakojimuose yra vienas ryškiausių riboženkliu, nusakančiu lietuviškos ir ispaniškos elgesio kultūrų skirtumus. Simbolinè ispanų reprezentacija yra didelis vaikui skiriamas dėmesys, o lietuvius reprezentuoja santūrumas vaiko atžvilgiu:

Ten [Ispanijoje. $-A$. D.] vaikais visi labiau užsiima. Svetimi visada pakalbins, padovanos bandelę. Labai didelis atvirumas. Pavyzdžiui, žaidimų aikštelèse jie labai moka užsiimti, pažaisti. Mamos bendrauja, kalbina vaikus. Ju pliusas, kad jie vaikams labai moka skirti dèmesį. Gal net sakyčiau, kad vaikus labiau laiko sau lygiais negu mes (lietuvè, kelerius metus gyvenusi Ispanijoje).

Dėmesio, šilumos, meilès vaikui Ispanijoje milijoną kartu daugiau nei Lietuvoje. Dèl vaiko atjautos, šilumos - tai yra be galo vaikus mylinti šalis (lietuvè, gyvenanti Ispanijoje).

Pateikejjai atkreipia dèmesí, kad ispanai îprastai skiria vaikui daugiau demesio ne tik ji kalbindami, bet ir ji liesdami. O lietuviško elgesio bruožais laikoma didesnio atstumo išlaikymas, fizinio kontakto vengimas:

Jei Lietuvoj ateina pažiūrèti vaiko, tai žiūri, ir tiek. O čia - kai gimè sūnus, atvažiavo žmonos [ispanès. - A. D.] giminè, atsimenu, aš laikau tą vaiką ir jaučiu, kad jie tiesiog išalkę to vaiko. Nu ir ką daryti? Sakau: gerai, imkit, ir paleidau per rankas. Nors man pačiam tokia keista savijauta. <..> Arba vieną kartą kažkokia valytoja (ispanè): „duok man vaika, ir viskas“. Ką daryti? Galvoju, gal apsimesti, kad nesuprantu. Nu daviau... (lietuvis, susituokęs su ispane). Kai mano šeima [ispanai. - A. D.] atvažiavo iz vestuves ir pamatè, kad čia tèvai su mažu vaiku stovi ir niekas jų vaiko neliečia, jiems buvo labai keista. Ispanijoje mažą vaiką visi nori paturèti, visi nešioja, bučiuoja, visi kalbina. Mano vyrui [lietuviui. - A. D.] buvo labai keista, kad ir vyrai nori kieno nors kūdiki panešioti, netgi pakeisti jam sauskelnes (ispanė, gyvenanti Lietuvoje).

Anot pateikejju, intensyviam bendravimui vaikas Ispanijoje nuo pat mažumès yra aktyviau nei Lietuvoje ruošia- 
mas ne tik kreipiant i ji daug dèmesio, bet ir ji pati skatinant užmegzti kontaktą su aplinkiniais:

Mano vaikas žaidimų aikštelëje (čia Lietuvoje) susitiko savo draugus iš darželio. Ir jie net nepasisveikino! Aš taip susijaudinau, nes pagalvojau, kad jo jie nemègsta. Bet mano vyras [lietuvis. $-A$. D.] mane nuramino, sako: Lietuvoje iš dveju metų amžiaus vaikų tiesiog niekas nereikalauja, kad jie sveikintussi (ispanè, gyvenanti Lietuvoje).

Ne vienas pateikèjas riboženkli tarp lietuviško ir ispaniško elgesio randa aptardamas vaiko disciplinavimo klausimą. Pastebima, kad Lietuvoje tèvai yra griežtesni, dažniau vaikui sako "negalima“, labiau stengiasi vaikus disciplinuoti. $\mathrm{O}$ Ispanijoje tèvai, ir ne tik tèvai, vaikų atžvilgiu labiau tolerantiški:

Ispanijoje tèvai nėra tokie griežti. Jie tolerantiškesni vaikų norams. Lietuvoje disciplina, tèvai daug griežtesni: dažniau vaikui sako „negalima“ ir užkerta kelią vaiko fantazijos vystymuisi. Ispanijoje, jei kokiam oro uoste koks vaikas baltais drabužiais voliojasi ant grindų, niekas nekreipia dèmesio, neduoda pastabų tèvams. Priešingai - nusišypso ir dar paploja tèvams: visi supranta, visi turèjo tokių pačių momentų (lietuvè, gyvenanti Ispanijoje).

Pateikèjams ispaniško elgesio simbolinè reprezentacija yra itin intensyvus vaiko globojimas:

Man labai keista, kad mano vyras [lietuvis. $-A$. D.] nekreipia demesio, jei vaikas lipa ant palangès. Dèl saugumo Ispanijoje visi daug daugiau jaudinasi. Kai grižtu i Ispanija, visi sako, kad aš labai atsipalaidavusi - per daug nebėgioju, neisterikuoju. O čia man atrodo, kad aš labai stresuoju, nes visi labai relaksuoja. Jūs čia visada sakote: nieko tokio (ispanè, gyvenanti Lietuvoje).

Kartais Ispanijoje man būdavo juokinga žiūrèti, kaip koks nors tèvelis visas stenėdamas, nugarą susièmęs, savo vaikeliui mauna kojines, batus riša, nors tas vaikelis, mano supratimu, pats puikiausiai galètų susitvarkyti (lietuvis, susituokęs su ispane).

Lietuvių elgesio su vaiku kultūrai, gretinant ją su ispanu, priskiriamas bruožas - ankstyvas vaiko savarankiškumo skatinimas ir pripažinimas: Lietuvoje vaikas labai anksti pradeda pats valgyti. Ispanijoje mamos ilgiau maitina, kad daugiau suvalgytu ir kad bütu švaresnis < .. > Ispanijoje aštuoneriu metu vaikui dar niekas neduoda gaminti maisto, tepti sumuštinio, siūti. Lietuvoje, mano pastebejimu, tai yra iprasta (ispanè, gyvenanti Lietuvoje).

Šios lietuviško ir ispaniško elgesio simbolinès reprezentacijos išryškèjo analizuojant migracijos kontekste gyvenančių lietuvių ir ispanų pateikejju naratyvus, kuriuose kalbama apie kasdieni rūpinimąsi vaiku.

\section{Lietuva versus Prancūzija}

Lietuvių ir prancūzų pateikèju grupejje buvo išskirtos visai kitokio pobūdžio simbolinès reprezentacijos, žyminčios takoskyrą tarp šių tautų rūpinimosi vaiku kultūrų. Esminiai skirtumai išryškejjo aptariant mandagumo, dienotvarkès ir kūdikio priežiūros klausimus.

Vienas pagrindinių elgesio su vaiku ypatumų, ì kuri atkreipè dèmesi didelè dalis pateikèju - skirtinga samprata, kaip ir kada reikia mokyti vaiką mandagumo. Pasak daugelio, Prancūzijoje 
vaiko mandagumo ugdymui skiriama itin daug demesio, Lietuvoje vaikas mandagumo imamas mokyti vèliau ir ne taip intensyviai:

Lietuvoje maži vaikai praktiškai niekada nesako "ačiū", bet lietuviams tai nèra problema. Čia žmonès to tiesiog negirdi. Prancūzijoje tai yra labai svarbu: jei vaikas nepasako "labas", "viso gero", "ačiū" - jis yra "mal éduqué“" (blogai išauklètas), o tai reiškia: tèvai netinkamai ji auklëja. Labai didelis teisimas. $\mathrm{O}$ čia: nepasakè „ačiū" - nieko tokio, jis turi visą gyvenimą to išmokti (prancūzè, gyvenanti Lietuvoje).

Prancūzijoje, atèjus svečiams, visi vaikai turi ateiti su jais pasisveikinti, juos priimti. Nepastebejjau, kad iš vaikų to būtu reikalaujama Lietuvoje (prancūzè, gyvenanti Lietuvoje).

Kita svarbi takoskyra tarp lietuviško ir prancūziško elgesio su vaiku ryškejja kalbant apie dienotvarkès organizavimą ir režimą. Tiksli dienotvarkè ir režimas tai itin svarbios prancūziško elgesio su vaiku simbolinès reprezentacijos. $\mathrm{O}$ lietuviško elgesio su vaiku simboliu pateikèju pasakojimuose yra nestruktūruota dienotvarkè. Už prancūzo ištekëjusi lietuvè teigia:

Va kas man iš prancūzu patinka - jie sako: miegas, valgymas, prausimasis, apsirengimas -4 dalykai, kur vaikas negali prieštarauti. Laikas miegoti - negali būti: aš nenoriu, dar 10 minučių. Ne. Reikia valgyti - reikia valgyti, reikia rengtis reikia rengtis. $<\ldots>$ Man lietuviai draugai skundžiasi: kaip jūs sumigdot tuos vaikus? Jie vargsta iki 11 ir iki 12. Ju vaikai nemiega, isterikuoja. Pas mus nebūna tokio dalyko, nes mes nuo pat kūdikio taip darem.
Vis dèlto ši pateikèja pripažịsta, kad prancūziška dienotvarkès organizavimo praktika jai kaip lietuvei yra priimtina tik iki tam tikros ribos:

[Prancūzijoje. $-A$. D.] kūdikị 8 val. mama padeda i lovytę, vaikas gali verkti, ji prie jo neis. 10 minučiu gali verkti. Ji nekreipia dẻmesio, kažką daro, gurkšnoja vyną, valgo sūrí. Po 10 minučiu nueina, truputị pačiūčiuoja ir vèl paguldo. Jis vèl 10 minučiu verkia. Taip, kol tas vaikas išvargsta ir užmiega. Su pirmu vaiku aš bandžiau ir matau, kad aš negaliu. Ir sakau: aš ne prancūzè, aš negaliu, man vaikas verkia - aš einu pas ji. Buvo daug pas mus visokių nemalonumu, bet aš nepasikeičiau ir dabar aš jau darau, kaip man atrodo geriau, kaip man širdis sakè. $\mathrm{O}$ jie nežiūri, kaip širdis sako. Jie žino, kad ju mama taip daré, drauge taip daro, močiutè - visi, ir jie žino, kad tokia sistema veikia ir pagal tą sistemą taip ir daro.

Taip pat išryškèja ryškūs skirtumai aptariant kitus kūdikio priežiūros klausimus. Lietuviškos rūpinimosi vaiku kultūros simbolis daugelio pateikejjų pasakojimuose yra kūdikio miegojimas kartu su tèvais:

Prancūzijoje vaikai nemiega tėvų lovoje. Jei nori maitinti, turi eiti $\mathfrak{i}$ vaiku miegamaji. Nèra taip kaip Lietuvoje, kad mamos su kūdikiais miega kartu: nori papo - gerai, paimk. Mes [prancūzai. - $A$. D.] manome, kad pirmiausia yra pavojinga miegoti su kūdikiu. $<\ldots . .>$ Ir taip pat mes tikime, kad lova yra žmonai ir vyrui, ne vaikams. Vaikai turi savo lovas. Mūsu vyresnèlis nuo 3 dienu miegojo savo lovoje, savo miegamajame (prancūzè, gyvenanti Lietuvoje).

Ne visi, tačiau daugelis pateikejų lietuvišką (skirtingai nei prancūzišką) rūpinimosi kūdikiu kultūrą tapatina su 
ilgu vaiko žindymu. Prancūzè, gyvenanti Lietuvoje, teigia:

Lietuvoje būti gera mama reiškia būti mama, kuri žindo minimum iki metų. Kuri žindo iki 2 - jau yra supermama. Prancūzijoje taip nèra. Gera mama Prancūzijoje yra ta, kuri grižta i darbą dirba, neša namo pinigus, pasirūpina vaikais ir namais, gamina valgi ir visa kita, kuri yra žmona, draugè... o ne tik žindo. Jei žindai - viskas tvarkoj. Tai yra pasirinkimas. Lietuvoje, jei nežindai - nesi normali. Su pirmu vaiku aš jaučiau tokì spaudimą! Aš pasakysiu, man nepatiko žindyti. Lietuvoje tai pasakyti yra šokiruojantis dalykas. Lietuvoje geriau sakyti: "neturiu pieno". Bet juk neturèti pieno yra neimanoma. Tavo kūnas gamina tuo daugiau pieno, kuo dažniau tu prie krūties glaudi kūdikị. Neįmanoma neturèti pieno, bet tu gali rinktis nežindyti! Bet Lietuvoje sako: „kaip tu nenori?!”

Lietuvei, ištekèjusiai už prancūzo, žindymo kultūra taip pat yra svarbus lietuviško ir prancūziško elgesio su kūdikiu skiriamasis ženklas:

Kai antram vaikui buvo gal 5 mėnesiai, mano vyras papasakojo savo mamai ir močiutei, kad žmona nakti dar eina žindyti. Buvo tokia reakcija: „ką?! dar žindo? ir naktį?! Čia išvis!“ Jam tas padare dideli presingą. Jis mane pradëjo stumti į kampą: kas čia per žindymai naktį! Aš pats negaliu išsimiegoti! Buvo daug nervų. Aš tada sau iškèliau grynai žmogišką klausimą: ar vyras, ar kūdikis - kuris yra tikrai ne pasaulio bamba, bet, kita vertus, jis yra absoliu- čiai bejejgis. Ir aš nusprendžiau sau, kad aš kitaip negaliu - aš renkuosi antrajji variantą. Po to su trečiu vaiku jau nuosaikesnis buvo vyro požiūris, jis gal susitaikè, gal tarp kitu prancūzų pasikeitè požiūris.

Šios lietuviško ir prancūziško elgesio simbolinès reprezentacijos atsiskleidè analizuojant migracijos kontekste gyvenančių lietuvių ir prancūzu pateikejju naratyvus, kuriuose kalbama apie kasdienį rūpinimąsi vaiku.

Išanalizavus dvi skirtingas perspektyvas - pateikèju, kuriančiu ryšius su Lietuva ir Ispanija, bei pateikeju, gyvenančių lietuvių ir prancūzų kultūrų sankirtoje, - išryškèjo skirtingi lietuvius nusakantys bruožai. Lietuviu ir ispanu pateikèju naratyvuose lietuviško elgesio su vaiku simbolinès reprezentacijos yra santūrumas, griežtumas, intensyvus ir ankstyvas savarankiškumo skatinimas. Pateikèjams gretinant lietuvišką ir prancūzišką elgesio su vaiku kultūras, lietuvišką elgesį nusako atlaidumas ir vaiko poreikių sureikšminimas.

Šie pastebejjimai leidžia patvirtinti teigini, kad konstruojant etnines simbolines reprezentacijas, labai svarbu yra tai, kokia kultūra yra kito pozicijoje. Tam tikrą tautą ar kultūrą nusakančiomis simbolinemis reprezentacijomis gali tapti vis kiti kasdienio elgesio aspektai priklausomai nuo to, kokiomis savybèmis pasižymi arba nepasižymi kito pozicijoje esanti tauta ar kultūra.

\section{IŠVADOS}

Tyrimas parodè, kad susidūrimo su kitu situacijoje kasdienybès detalès tampa tautą arba šali reprezentuojančiomis simbolinėmis reprezentacijomis: migracijos situacijoje susitikusiems lietuviams, ispanams ir prancūzams etninès tapaty- 
bės ženklais tampa tokie rūpinimosi vaiku kultūros aspektai kaip vaiko savarankiškumo samprata, tèvų elgesys vaiko ligos atveju, vaiko socializacija prie stalo, tèvo vaidmuo šeimoje.

Tyrimas atskleidè, kad konstruojant etnines simbolines reprezentacijas, labai svarbu yra tai, kokia kultūra yra kito pozicijoje. Tam tikrą tautą ar kultūrą nusakančiomis simbolinėmis reprezentacijomis gali tapti vis kiti kasdienio elgesio aspektai - priklausomai nuo to, kokiomis savybėmis pasižymi arba nepasižymi kito pozicijoje esanti tauta ar kultūra. Lietuvių ir ispanų pateikeju pasakojimuose lietuviško elgesio su vaiku bruožais laikomas santūrumas, griežtumas, intensyvus ir ankstyvas savarankiškumo skatinimas. $\mathrm{O}$ lietuviams būdingą elgesi gretindami su prancūziška elgesio kultūra, pateikèjai lietuvišką elgesi tapatina su atlaidumu ir vaiko poreikių sureikšminimu.

Tyrimas patvirtina, kad ne mažiau sudètingas yra asmeninio etninio tapatumo konstravimo procesas. Vienu atveju kilmès kultūrą nusakančios simbolinès reprezentacijos padeda apsibrèžti asmeninę etninę tapatybę. Ši situacija susidaro, kai individui priimtini jo kilmès šali reprezentuojantys elgesio modeliai. Pavyzdžiui, dauguma šio tyrimo dalyvių

\section{Literatūra ir nuorodos}

1 Vida Savoniakaite, Antropologija ir etnologija postmoderybeje. Savas ir kitas šiuolaikiniais požiūriais. Sud. V. Savoniakaitè. Vilnius: LII leidykla, 2014, p. 73-96.

2 Vida Savoniakaitè, Tapatybè, Lietuvos tapatybe: etnologijos ir antropologijos enciklopedija. Sud. V. Savoniakaitè. 2010. <http://identitetas.mch.mii.lt> [žriūrèta 201710 15].

3 Orvar Löfgren, The Nationalization of Culture, Ethnologia Europeae, XIX, 1989, p. 5-23. buvo įsitikinę, kad jų kilmės šalyje îsitvirtinęs elgesys vaiko ligos atveju yra racionalus ir teisingas. Daugeliui pateikèju kalbant apie ši rūpinimosi vaiku aspekta, buvo sava tai, kas būdinga jo kilmès šaliai. Daugelyje pasisakymų vaiko ligos klausimu slypėjo žinia: „mes lietuviai - elgiamès taip" arba „mes - ispanai - elgiamès taip".

Tačiau ne visada kilmès šali nusakančiomis simbolinėmis reprezentacijomis pripažìstama rūpinimosi vaiku praktika pateikèjui yra priimtina. Susidūrimo su kitu situacijoje atrastas kitas elgesio modelis gali pasirodyti esantis labiau pagristas, kuriantis šiltesnius santykius ar pan. Pavyzdžiui, didelei daliai lietuvių pateikèjų savastimi tapo Pietų Europoje išmokta bendro šeimos pietavimo tradicija, kai kuriuos pateikejjus ispanus žavejo Lietuvoje atrastas vaiko savarankiškumas, o kai kuriuos prancūzus - Lietuvai būdingi ne tokie aukšti reikalavimai mažą vaiką mokant mandagumo. Panašu, kad tokioje situacijoje sava ir kita apsikeičia vietomis: kilmès šaliai būdingas elgesys tampa svetimu, o kitoje bendruomenèje nusistovèję kultūriniai elgesio modeliai - savu. Etninio tapatumo konstravimas migracijos kontekste yra ypatingai sudètingas ir ivairiakryptis procesas.

\footnotetext{
4 Ten pat, p. 15.

5 Migracija pačia bendriausia prasme apibrèžiama kaip žmonių mobilumas. Sąvoka „migrantai“ apima emigrantus, imigrantus, transmigrantus. Emigrantus ir imigrantus apibrèžia ilgalaikis ar trumpalaikis buvimas kitoje šalyje. Transmigranto sąvoka nurodo, kad žmonès dalyvauja, identifikuojasi, kuria ryšius iš karto su keliomis valstybemis. (Darius Daukšas, Migracija, Lietuvos tapatybe: etnologijos ir antropologijos enciklope-
} 
dija. Sud. V. Savoniakaitè. 2010. <http://identitetas.mch.mii.lt> [žriūrèta 201710 15]) Remdamasi šiais apibrèžimais, kai kalbu apie migraciją šiame straipsnyje, turiu galvoje ne tik emigrantus ar imigrantus, bet ir jų šeimos narius.

6 Ariane Utomo, Mother tongue, mothering, and (transnational) identity: Indonesian mothers in Canberra, Australia, ASEAS - Austrian Journal of South-East Asian Studies 7 (2), 2014, p. 165-182.

7 Livia Jimenez Sedano, Spanish people don't know how to rear their children! Parenting in Global Perspective: Negotiating Ideologies of Kinship, Self and Politics. Sud. Ch. Faircloth, D. M. Hoffman, L. L. Layne. London, New-York: Routledge, 2013, p. 169-183.

8 Hemalatha Ganapathy-Coleman, Raising "Authentic" Indian Children in the United States: Dynamism in the Ethnotheories of Immigrant Hindu Parents, Ethos 41 (4), 2013, p. 360-386.

9 Löfgren, p. 12.

10 Darius Daukšas, Būti lietuviu čia ir ten: migrantų iš Lietuvos Norvegijoje atvejis, Lietuviškasis tapatumas šiuolaikinès emigracijos kontekstuose. Sud. V. Čiubrinskas. Kaunas: Vytauto Didžiojo universitetas, 2011, p. 119-139; Darius Daukšas, Lietuvos lenkai: etninio ir pilietinio tapatumo konstravimas ribinėse zonose, Lietuvos etnologija; socialines antropologijos ir etnologijos studijos 12 (21), 2012, p. 167-193; Darius Daukšas, Lithuanians in Norway: Between 'Here' and 'The$\mathrm{re}^{\prime}$, Urbanities: the Journal of the IUAES Commission on Urban Anthropology 3 (2), 2013, p. 51-68; Irena Merkienè, Rasa Paukštytė-Šaknienè, Vida Savoniakaitè, Žilvytis Šaknys, Pietryčiu Latvijos lietuviai: tapatumo išraiška, etninès ir kultūrinès orientacijos. Vilnius: Versus Aureus, 2005; Auksė Noreikatė, Lietuvos latvių kultūrinis tapatumas: regioninès ypatybès, Acta humanitarica universitatis Saulensis, 14, 2012, p. 78-90; Rasa Paukštytè, Latvijos lietuvių krikštynos po 1991 metų, Liaudies kultūra 3, 2000, p. 30-33; Rasa Račiūnaitè, Sava ir svetima žmogaus gyvenimo ciklo papročiuose, Tautinio tapatumo ir tautinès kultūros problemos: lietuviai ir lituanistika už Lietuvos ribu XX $a$. Red. J. Girdzijauskas. Vilnius: Lietuviu literatūros ir tautosakos institutas, 2001, p. 83-91; Vida Savoniakaitè, Latvijos lietuvių kūrybos stebejjimai, Lituanistica 3-4, 2000, p. 93-103; Vida
Savoniakaitè, Etniškumas. Lietuviai Latvijos pasienyje, Lietuvos etnologija: socialines antropologijos ir etnologijos studijos 1 (10), 2001, p. 217230; Vitalija Stravinskienè, Tarp sugyvenimo ir priešiškumo: tarpetniniai santykiai Rytų ir Pietryčių Lietuvoje (1944-1953 m.), Savas ir kitas šiuolaikiniais požiūriais. Sud. V. Savoniakaitè. Vilnius: LII leidykla, 2014, p. 163-182; Žilvytis Bernardas Šaknys, Pietryčių Latvijos lietuviai: kultūra, etniškumas ir bendraamžių bendrija, Lietuvos etnologija: socialines antropologijos ir etnologijos studijos 1 (10), 2001, p. 231-250; Jurijus Unukovičius, Lietuvių ivvaizdis Vilniaus krašto slaviakalbių gyventojų akimis, Savas ir kitas šiuolaikiniais požiūriais. Sud. V. Savoniakaitè. Vilnius: LII leidykla, 2014, p. 183-208.

11 Remiantis antropologès H. N. Fouts ir jos kolegu apibrèžimu, kultūra suprantama kaip socialiai perduodamos žinios, vertybės bei elgsena, daugiau ar mažiau isitvirtinusios tam tikroje socialinejje grupeje. (Hillary Fouts, Barry Hewlett, Michael Lamb, A Biocultural Approach to Breastfeeding Interactions in Central Africa, American Anthropologist 114 (1), 2012, p. 123-136).

12 Netikètai susidraugavau su Lietuvoje gyvenančia, už lietuvio ištekejjusia ir čia vaikus auginančia ispane. Augindamos to paties amžiaus vaikus dažnai izsileisdavome i smulkmeniškus ispanų ir lietuvių elgsenos skirtumų bei panašumų aptarinejjimus. Ne kartą teko dalyvauti šeimyniniuose pasibuvimuose, kuriuose susitikdavo lietuviai ir ispanai. Turèjau ne vieną proga pastebėti kai kuriuos ispanu ir lietuviu tarpasmeninio susitikimo situacijoje išryškejjančius kultūrinius skirtumus arba apie juos išgirsti neformaliuose pokalbiuose.

13 Vieno interviu pabaigoje paaiškejo, kad minimas lietuvis yra Lietuvos rusas, tačiau iš Prancūzijos kilusi pateikèja patikslino, kad tai visiškai nekeičia esmès, nes jis yra užaugęs Lietuvoje ir perèmęs daugelį lietuvių elgesio kultūros bruožu. Kito interviu metu pateikèjas, besitapatinantis su lietuviška elgesio kultūra, nurodè, kad jis yra žydų kilmès.

14 Vida Savoniakaitė, Etniškumas, Lietuvos tapatybé: etnologijos ir antropologijos enciklopedija. Sud. V. Savoniakaitè. 2010. <http://identitetas.mch. mii.lt> [žriūrèta 201710 20] 